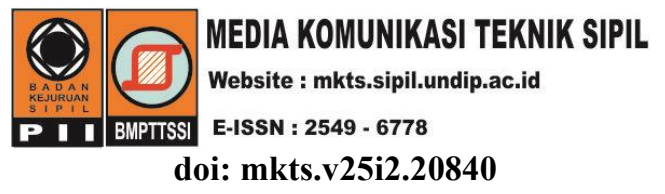

\title{
Liquefaction Susceptibility Zonation in Lempuing Subdistrict, Bengkulu City, Indonesia
}

\author{
"Lindung Zalbuin Mase \\ Department of Civil Engineering, Faculty of Engineering, University of Bengkulu, Bengkulu, Indonesia \\ $\left.{ }^{*}\right)$ Imase@unib.ac.id
}

Received: 30 October 2018 Revised: 8 November 2019 Accepted: 19 November 2019

\begin{abstract}
Zonation of liquefaction potential is the important thing in understanding the liquefaction impact on an area. The liquefaction Severity Index (LSI) method can be applied to determine the liquefaction vulnerability level. This paper presents a study of liquefaction using LSI method to compose the liquefaction vulnerability map in a coastal area of Bengkulu City i.e., Lempuing Subdistrict. This study was conducted by analyzing CPT data in Lempuing Subdistrict to obtain the Factor of Safety and the probability of liquefaction. Peak Ground Acceleration (PGA) was assumed as 0.5g, which refers to SNI 03-1726-2012. Furthermore, the value of liquefaction probability and factor of safety obtained was analyzed to obtain LSI index and adjusted to the specific categories i.e., very low $(0<L S I<15)$, low $(15<L S I<35)$, moderate $(35<L S I<65)$, high $(65<L S I<85)$, and very high $(85<L S I<100)$. Based on the analysis result, Lempuing Subdistrict was categorized as a very high to the very low susceptible area to liquefaction. The very high susceptible area was located on the eastern Lempuing Subdistrict bordering to the Gading Cempaka Subdistrict. The high susceptible area was located on the northern Lempuing Subdistrict bordering the Tanah Patah Subdistrict. Moderate to very low susceptible areas were located in the middle, west, and south of Lempuing Subdistrict.
\end{abstract}

Keywords: Liquefaction, vulnerability, microzonation, liquefaction severity index

\begin{abstract}
Abstrak
Mikrozonasi potensi likuifaksi adalah hal penting dalam upaya penanggulangan likuifaksi pada suatu daerah. Salah satu metode yang digunakan dalam menggambarkan mikrozonasi likuifaksi adalah Liquefaction Severity Index (LSI). Sebagai implementasi pemahamaman likufaksi, sebuah penelitian likuifaksi yang berkaitan dengan metode LSI dilakukan pada kawasan pesisir Kota Bengkulu, yaitu Kelurahan Lempuing. Penelitian ini dilakukan dengan menganalisis data CPT (Cone Penetration Test) untuk memperoleh faktor keamanan likuifaksi dan probabilitasnya. Percepatan tanah puncak (PGA) diasumsikan sebesar 0.5g, yang mengacu pada peraturan SNI 03-1726-2012. Selanjutnya probabilitas likuifaksi dan faktor aman likuifaksi dihitung untuk mendapatkan indeks LSI dan dikelompokkan ke dalam kategori kerentanan, yang terdiri dari very low (sangat rendah) $(0<L S I<15)$, low (rendah) $(15<L S I<35)$, moderate (sedang) $(35<L S I<65)$, high (tinggi) $(65<L S I<85)$, and very high (sangat tinggi) $(85<L S I<100)$. Hasil analisis tersebut selanjutnya disajikan dalam bentuk peta kerentanan dengan bantuan perangkat lunak ArcGIS. Berdasarkan hasil analisis, Kelurahan Lempuing dikategorikan sebagai area dengan kerentanan sangat tinggi sampai dengan sangat rendah. Bagian timur Lempuing yang berbatasan dengan Kelurahan Gading Cempaka dikategorikan sebagai area dengan kerentanan sangat tinggi. Area dengan kerentanan tinggi terdapat pada bagian utara Lempuing yang berbatasan dengan Kelurahan Gading Cempaka. Area kerentanan sedang sampai dengan sangat rendah terletak pada bagian tengah, barat, dan selatan Kelurahan Lempuing.
\end{abstract}

Kata kunci: Likuifaksi, kerentanan, mikrozonasi, liquefaction severity index

\section{Introduction}

Liquefaction is a phenomenon in sandy soil, due to loss of the shear strength caused by dynamic loads, such as earthquakes. The loss of shear strength causes the loss of bearing capacity in soil. Then, sandy soils behave, as liquid. Liquefaction had been detected in many locations in Indonesia, i.e. 
Bengkulu in 2000 as reported by Mase (2015), Yogyakarta in 2000 as reported by Yogatama and Fathani (2013) and Mase (2017a), Bengkulu in 2007 as reported by Mase (2017b), and Padang in 2009 (Hakam, 2012). In Bengkulu, liquefaction phenomena occurred in 2000 and 2007. Those liquefactions were caused by two large earthquakes in 2000 and 2007 (Mase \& Sari, 2015). Liquefaction phenomena, such as ground failures, sand boils, and lateral spreads, were found along with coastal areas in Bengkulu City during the earthquakes. Mase (2017b) mentioned that along the coastal area of Bengkulu Province could be possible to undergo liquefaction during the 2007 Earthquake.

Lempuing Subdistrict is a coastal area in Bengkulu City, which is dominated by sandy soil. This area experienced liquefaction in 2000 and 2007, which were caused by two large earthquakes. Liquefaction potential in Lempuing Subdistrict had been investigated for the last three years. Misliniyati et al. (2013) analyzed liquefaction potential in Lempuing Subdistrict using Cone Penetration Test (CPT) data. The result of this study explained that liquefaction potentially occurred in this area.

Monalisa (2014) continued Misliniyati et al. (2013) study by using the same data of Misliniyati et al. (2013). The study was conducted by performing the probability analysis to investigate liquefaction potential. The result also showed that the area could be liquefied. Mase and Somantri (2016a and 2016b) performed a study of liquefaction potential in Lempuing Subdistrict by using the concept of critical Peak Ground Acceleration (PGA). The result of that study showed that at a depth of 0 to 6 $\mathrm{m}$, Lempuing soil sites could undergo liquefaction during the 2007 Earthquake. Mase (2017b) had investigated the liquefaction potential along the coastal area of Bengkulu Province based on nonlinear analysis of liquefaction potential using Finite Element Method proposed by Iai et al. (1992). One of the areas investigated by that study is Lempuing Subdistrict.

Based on the results, Mase (2017b) concluded that the Lempuing Area could be very vulnerable to liquefaction. The excess pore pressure ratio on Lempuing Subdistrict is about one. It indicates that the liquefaction is possible to happen in Lempuing Subdistrict. Mase (2018) examined the empirical methods of liquefaction to assess the liquefaction potential along the coastal area of Bengkulu City. Mase (2018) also compared the empirical methods to the liquefaction evidence found during the 2007 Earthquake in Bengkulu City. The results showed that Idriss and Boulanger (2008) method could be the most appropriate empirical method to predict liquefaction in the coastal area of Bengkulu City.
In general, the previous studies were focused on the empirical and analytical methods to predict liquefaction along the coastal area of Bengkulu City, whereas the zonation of liquefaction vulnerability has not been performed yet. However, the previous studies have reached a conclusion that along the coastal area of Bengkulu City is very vulnerable to liquefied, including Lempuing Subdistrict.

This study presents a zonation of liquefaction vulnerability in the Lempuing Subdistrict. A Liquefaction Severity Index (LSI) method proposed by Sonmez and Gokceoglu (2005) based on the empirical analysis of liquefaction is implemented to generate the liquefaction potential map in Lempuing Subdistrict. Furthermore, this study is expected to provide a deeper understanding of liquefaction vulnerability along the coastal area of Bengkulu city in general and the Lempuing Subdistrict Region in Bengkulu City in particular.

\section{Empirical analysis liquefaction potential}

Basically, the liquefaction study was analyzed by using the simplified procedure method (Seed \& Idriss, 1971). The concept of this method is to compare the Cyclic Stress Ratio (CSR) and Cyclic Resistance Ratio (CRR).

Seed and Idriss (1971) proposed the empirical correlation to estimate the liquefaction potential. $C S R$ is the cyclic stress which is produced by the earthquake load. CSR is expressed in Equation 1,

$C S R=0.65 . r_{d}\left(\frac{\sigma_{v}^{\prime}}{\sigma_{v}}\right) \cdot\left(\frac{a_{\max }}{g}\right)$

where, $r_{d}$ is depth reduction factor $\left(r_{d}=1-0.012 \mathrm{z}\right)$, $\sigma_{v}^{\prime}$ is effective stress of calculated depth, $\sigma_{v}$ is total stress of calculated depth, and $a_{\text {max }}$ is maximum PGA.

$C R R$ is the ratio which describes the resistance of the soil under dynamic load. Several researchers such as Seed and Idriss (1971), Youd and Idriss (2001), and Idriss and Boulanger (2008) had proposed the empirical correlation to estimate $C R R$ value. The value of $C R R$ can be estimated based on the secondary data from CPT, Standard Penetration Test (SPT), and Shear Wave Velocity $\left(V_{s}\right)$. In liquefaction studies, the secondary data that usually used is CPT. The reason of CPT usage is the economic factor and workability. The formula to determine $C R R$ based on CPT data was proposed based on the Idriss and Boulanger (2008) study. Mase (2018) suggested that for the coastal area of Bengkulu City, the Idriss and Boulanger (2008) 
empirical method is more reasonable to predict liquefaction potential. The $C R R$ equation based on CPT data is expressed in Equation 2,

$$
C R R_{M=7.5}=\exp \left(\begin{array}{l}
\frac{q_{c 1 N c s}}{540}+\left(\frac{q_{c 1 N c s}}{67}\right)^{2}-\left(\frac{q_{c 1 N c s}}{80}\right)^{3} \\
+\left(\frac{q_{c 1 N c s}}{114}\right)^{4}-3
\end{array}\right)
$$

Where $C R R_{M=7.5}$ is the cyclic resistance ratio on $M$ of $7.5 M_{w}, q_{c l N c s}$ is normalized overburden corrected cone tip resistance (obtained from Robertson \& Wride, 1998). However, the actual formula which is used to estimate the $C R R$ for other different earthquake magnitudes values is expressed in Equation 3,

$$
C R R=C R R_{M=7.5} \cdot M S F \cdot K_{\sigma}
$$

where $M S F$ is a magnitude scale factor (Idriss, 1999), and $K_{\sigma}$ is the overburden pressure factor (Seed, 1983).

Based on the previous equations, the Factor of Safety against liquefaction $\left(F_{S}\right)$ is computed by using Equation 4,

$$
F_{s}=\frac{C R R}{C S R}
$$

where $F_{S}$ is Factor of Safety against liquefaction $\left(F_{S}\right.$ $<1$, liquefaction potentially occurs, and $F_{S} \geq 1$, liquefaction doesn't potentially occur).

So far, the analysis of liquefaction potential is not only developed to investigate $F_{S}$ result but also the probability of liquefaction $\left(P_{L}\right)$. Juang et al. (2003) introduced the equation to determine the probability of liquefaction based on $F_{S}$, which is obtained from the comparison between $C R R$ and $C S R$. The probability of liquefaction based on Juang et al. (2003) is shown in Equation 5,

$$
P_{L}=\frac{1}{1+\left(\frac{F_{s}}{0.96}\right)^{4.5}}
$$

where $P_{L}$ is the probability of liquefaction.

\section{Liquefaction Severity Index (LSI)}

Analysis of the liquefaction analysis is not only limited to predict the probability of liquefaction but also to map the susceptible area to liquefaction or to generate the liquefaction hazard map. Sonmez \& Gokceoglu (2005) had proposed a method of the Liquefaction Severity Index $(L S I)$ to evaluate the risk level of liquefaction. This method used the value of liquefaction probability as the parameters to integrate LSI level. Nowadays, this method has been widely used in liquefaction study. LSI is quantified based on Equation 6,

$$
L S I=\int_{0}^{n} P_{L}(z) \cdot W(z) \cdot d z
$$

The values of $P_{L}(z)$ and $W(z)$ are obtained from Equations 7 to 10 ,

$$
\begin{aligned}
& P_{L}(z)=\frac{1}{1+\left(\frac{F_{s}}{0.96}\right)^{4.5}}, \text { for } F_{S}<1.411 \\
& P_{L}(z)=0, \text { for } F_{S}>1.411 \\
& W(z)=10-0.5 z, \text { for } 0 \leq \mathrm{z} \leq 20 \\
& W(z)=0, \text { for } 0 \mathrm{~m}
\end{aligned}
$$

where $L S I$ is liquefaction severity index, $P_{L}(z)$ is the probability of liquefaction based on depth function, $n$ is the analyzed depth (maximum up to $20 \mathrm{~m})$ and $W(z)$ is soil depth weight factor.

Once $L S I$ value had been determined, then the level of liquefaction susceptibility can be obtained. According to Sonmez and Gokceoglu (2005), the level of vulnerability in LSI method can be classified into five categories, which are shown in Table 1.

\section{Table 1. Level of LSI categories (Sonmez \&} Gokceoglu, 2005)

\begin{tabular}{clc}
\hline No & LSI Classification & The range of value \\
\hline 1 & Very high & $85 \leq L S I<100$ \\
2 & High & $65 \leq L S I<85$ \\
3 & Moderate & $35 \leq L S I<65$ \\
4 & Low & $15 \leq L S I<35$ \\
5 & Very low & $0<L S I<15$ \\
\hline
\end{tabular}

The implementation of LSI method had been used by many researchers in liquefaction studies. This is due to the fact that this method could describe the liquefaction potential and its vulnerability. In this study, the concept of $F_{S}$, probability, and level of susceptible area $(L S I)$ are combined to analysis the liquefaction potential. Therefore, the description of liquefaction potential can be seen and observed easily. In the previous explanation, it has been elaborated that Lempuing Subdistrict was still focussing on the liquefaction study in the coastal area of Bengkulu. The result of this study also expected to be considered in the geotechnical problem in Bengkulu related to the earthquake phenomenon that potentially occurs in Bengkulu. This study is expected to be able to accomplish the previous study that had been conducted in Lempuing Subdistrict. 


\section{Method of Study}

In this study, the in-situ test had been conducted to obtain the data by using CPT data. Then, the data obtained from the in-situ test was analyzed by using the equations that elaborated in the previous section. In detail, the methods are elaborated in the next subchapters.

\section{Data}

Data used in this study were collected from site investigation conducted by using the Cone Penetration Test in Lempuing Subdistrict. The layout of CPT points is shown in Figure 1. Maximum cone resistance is assigned to stop at QC of $100 \mathrm{~kg} / \mathrm{cm}^{2}$. It is caused by the condition of CPT equipment and in order to avoid the broken of equipment. At this resistance, soils were assumed to have reached the stiff material. Based on the data, the depth of stiff soil varies from $2 \mathrm{~m}$ to $10 \mathrm{~m}$. CPT 1,5 , and 6 had reached the stiff surface at $10 \mathrm{~m}$ depth, CPT 2 at $2 \mathrm{~m}$ depth, CPT 3 at $2.6 \mathrm{~m}$ deep, and CPT 4 at $6.2 \mathrm{~m}$ depth.

\section{Analysis}

The analysis conducted in this study had been conducted after CPT data collected. Step by step to analyze the liquefaction potential is elaborated in these points: (1) Collecting data of CPT test. The site investigation results are presented in Figure 2.
(2) Analyzing the $q_{c l N c s}$ and soil type based on the Method of Roberson and Wride (1998). (3) Estimating maximum peak ground acceleration. Based on SNI 03-1726-2012, the distribution of peak bedrock acceleration $\left(a_{\max }\right.$ at bedrock) in Bengkulu city is $0.4 \mathrm{~g}$ to $0.5 \mathrm{~g}$. In this study, peak bedrock acceleration was assumed of $0.5 \mathrm{~g}$, and the amplification factor was assumed of 1 (SNI 031726-2012). The maximum peak ground acceleration was computed by multiplying peak bedrock acceleration to the amplification factor. (4) Calculating CSR using Equation 1. In this study, groundwater level (GWL) was assumed at the soil surface to reflect the conservative condition. Unit weight in saturated condition $\left(\gamma_{\text {sat }}\right)$ was $20 \mathrm{kN} / \mathrm{m}^{3}$. It is obtained from the core drill test of the disturbed soil samples. (5) Calculation of the CRR using Equation 2. $C R R$ was determined by using Equation 3. The earthquake magnitude is assumed to be $\mathrm{M}_{\mathrm{w}}$ of $8.6 \mathrm{M}_{\mathrm{w}}$ (it was based on the 2007 earthquake magnitude scale $\left(\mathrm{M}_{\mathrm{s}}\right.$ of 8.5) and converted to $\mathrm{M}_{\mathrm{w}}$ scale). (6) Calculating $F_{S}$ using Equation 4, calculating the $P_{L}$ using Equation 5, calculating the integration of LSI Equation 6. This equation must consider the results from Equation 7 to 10. (7) Determining the specification of susceptible level based on Table 1, interpreting the result of $L S I$ as a susceptible map. This step should be performed by using the Geographic Informatics System to depict the distribution of LSI levels.

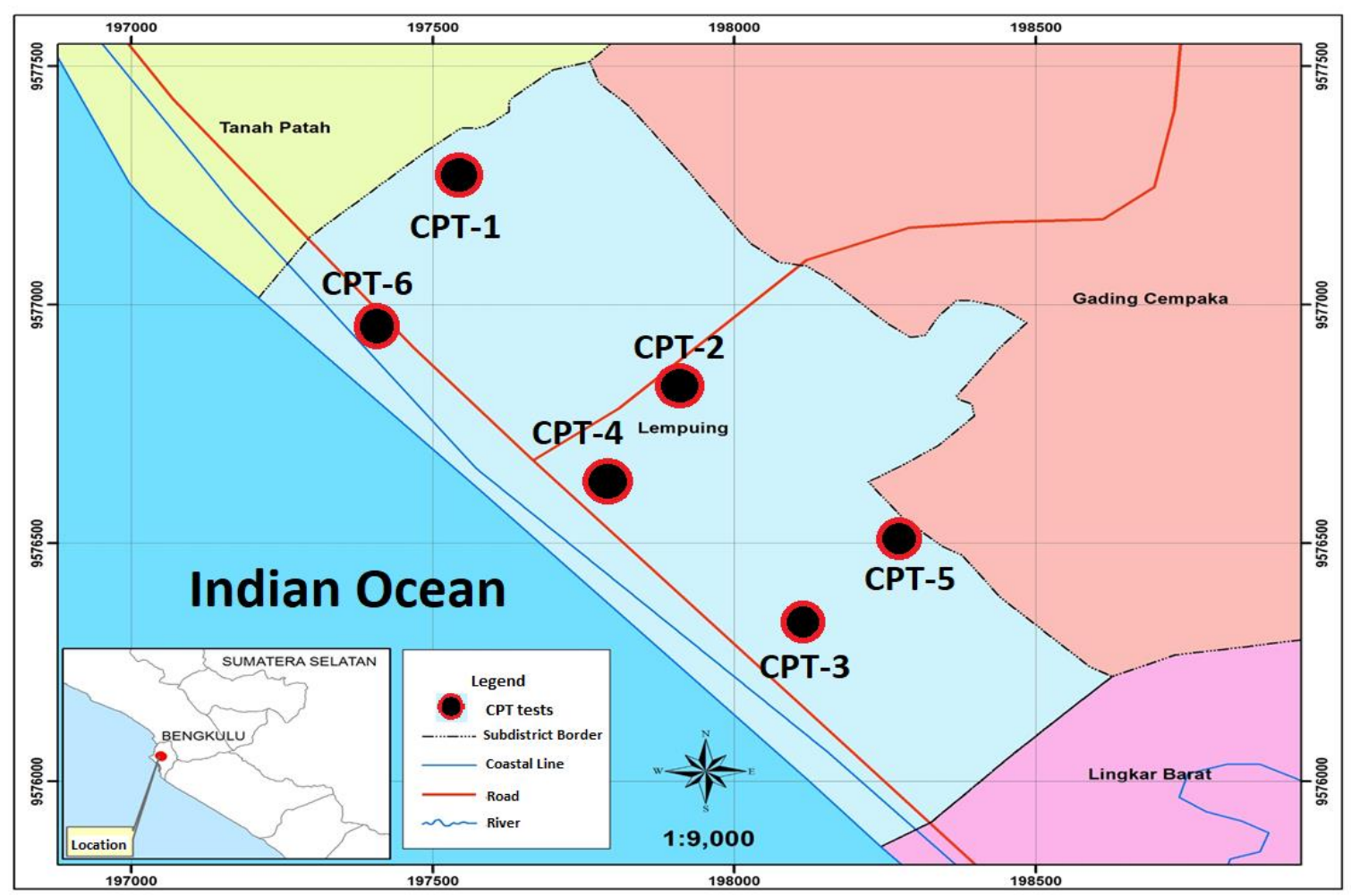

Figure 1. Study area and location of CPT tests 


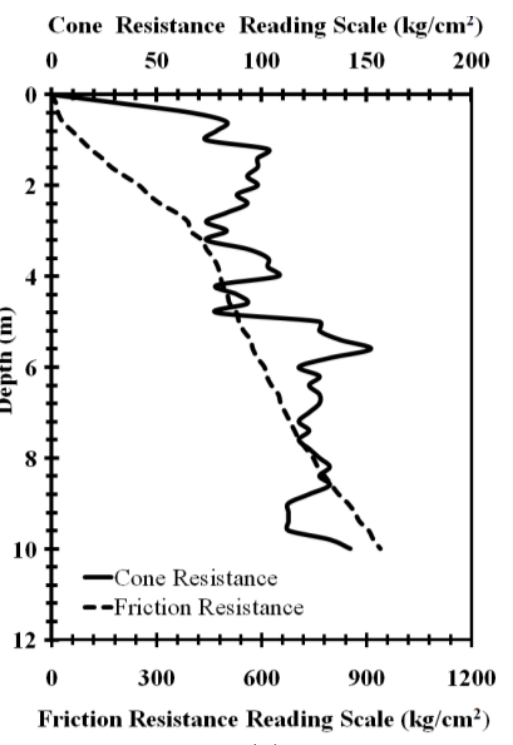

(a)

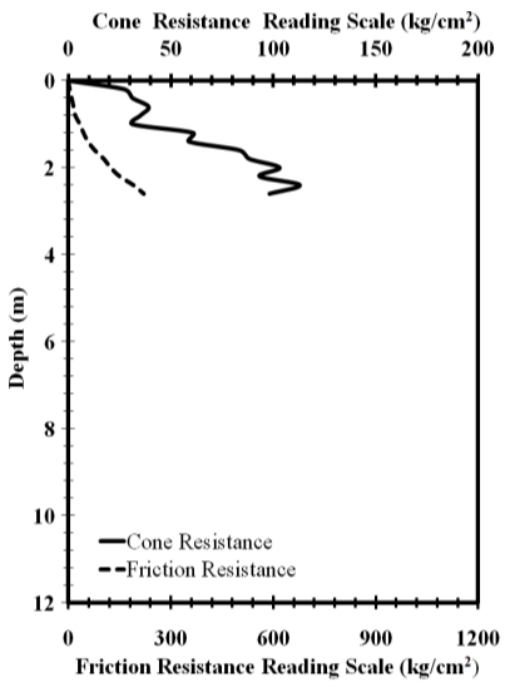

(c)

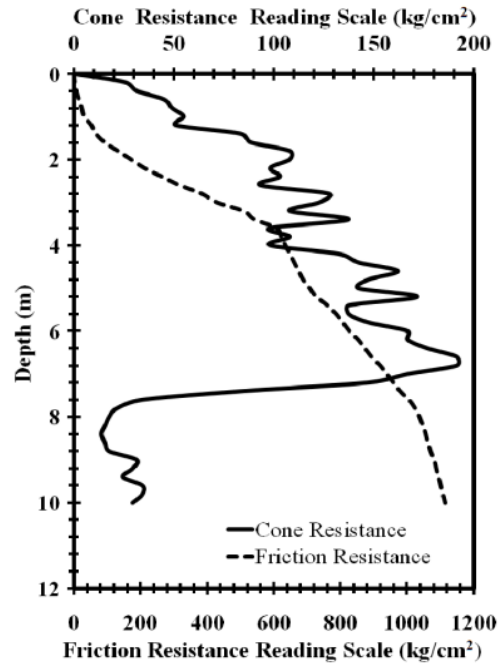

(e)

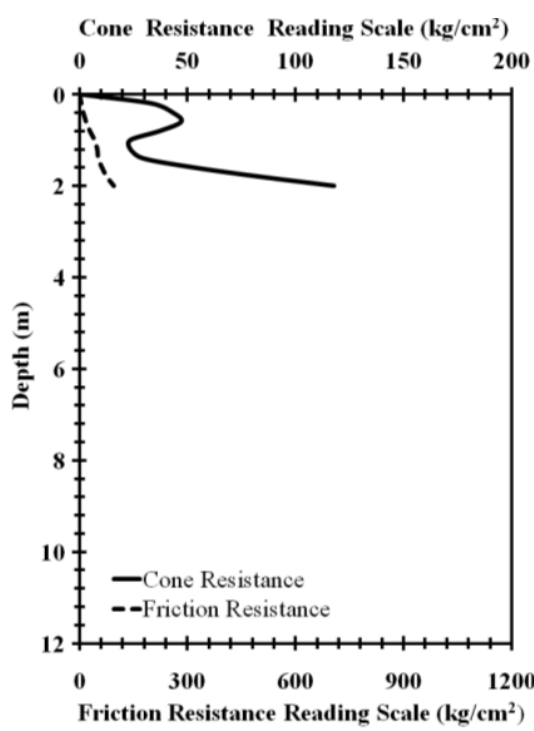

(b)

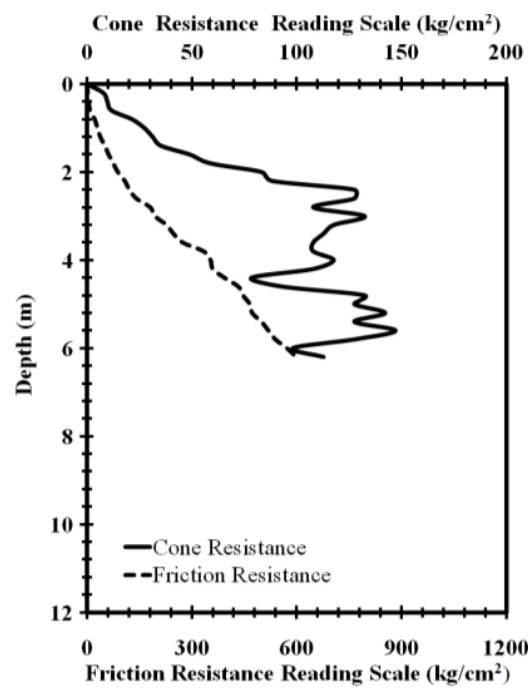

(d)

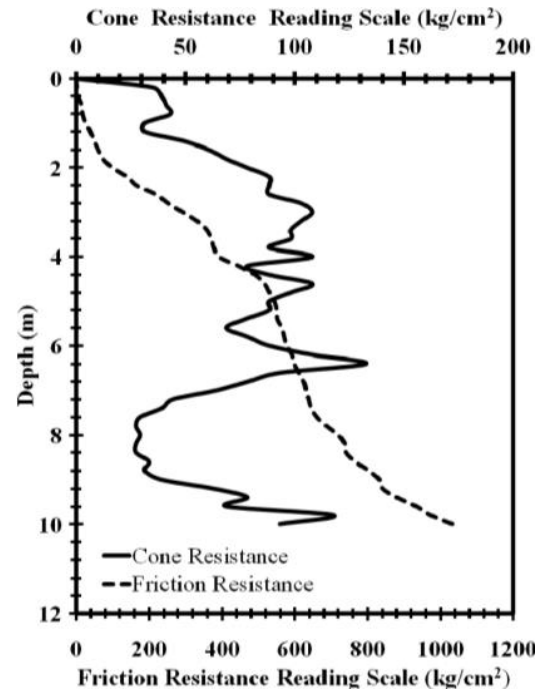

(f)

Figure 2. CPT data (a) point 1, (b) point 2, (c) point 3, (d) point 4, (e) point 5, and (f) point 


\section{Result and Discussion}

Result of this study included, i.e., $F_{S}$ at each depth, $P_{L}$ at each depth. Liquefaction severity index mapping, also based on $F_{S}$ and $P_{L}$ is also resulted from this study. Detail explanations of the results of this study are elaborated in the following subchapter.

\section{Soil site}

Based on site investigation and back analysis to the Robertson and Wride (1998) method for cone resistance, the soil site of this study area is dominated by sandy soil.

The factor of safety against liquefaction in Lempuing Subdistrict

$F_{S}$ of each CPT data is shown in Figure 3a. Based on the result interpreted in Figure $3 \mathrm{a}, F_{S}$ of all CPT points is less than 1 . It can be concluded that Lempuing Subdistrict is an unsafe area to liquefaction $\left(F_{S}\right.$ is less than 1$)$. Based on the overall analysis result, the maximum $F_{S}$ obtained is 0.375 , and the minimum $F_{S}$ is 0.054 . This result also confirms the results of Misliniyati et al. (2013) that analyzed $F_{S}$ against liquefaction in the same area. The results are also consistent with Mase and
Somantri (2016a and 2016b) and Mase (2017b), who stated that at first $5 \mathrm{~m}$ depth, the Lempuing Subdistrict could undergo liquefaction. Generally, the results have confirmed the field evidence of liquefaction during the 2007 Earthquake, which is reported by Mase (2018). The results of $F_{S}$ analysis are further analyzed to determine the distribution of susceptible area using LSI method.

\section{Probability of liquefaction in Lempuing Subdistrict}

$P_{L}$ in Lempuing Subdistrict is interpreted in Figure $3 b$. Based on the result in Figure 3b, the majority of $P_{L}$ of each CPT data is approximately reaching one. It can be concluded that the area is possible to be liquefied. Likewise, the distribution of the value of probability, based on the total data analyzed, minimum $P_{L}$ is 0.828 , and maximum $P_{L}$ is 0.946 . Those results are consistent with Monalisa (2014), who reported that $P_{L}$ in Lempuing Subdistrict is relatively high. In addition, the results also strengthen the study of Mase (2018) that stated that along the coastal areas of Bengkulu City, including Lempuing, could have a high possibility to liquefaction during the 2007 Bengkulu-Mentawai Earthquake. The results of $P_{L}$ combined with $F_{S}$ were used to the analysis of liquefaction vulnerability.

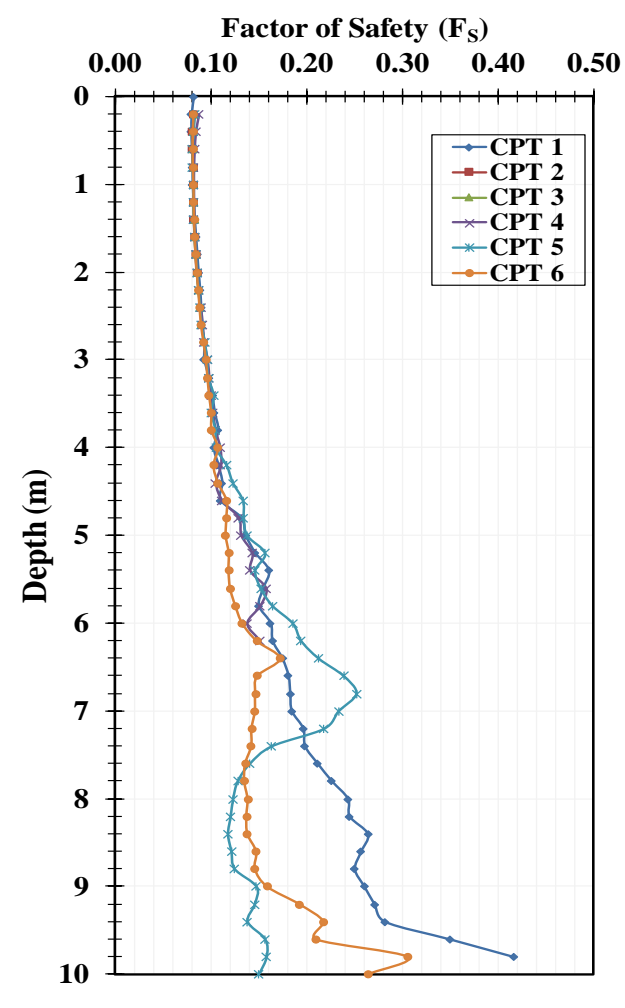

(a)

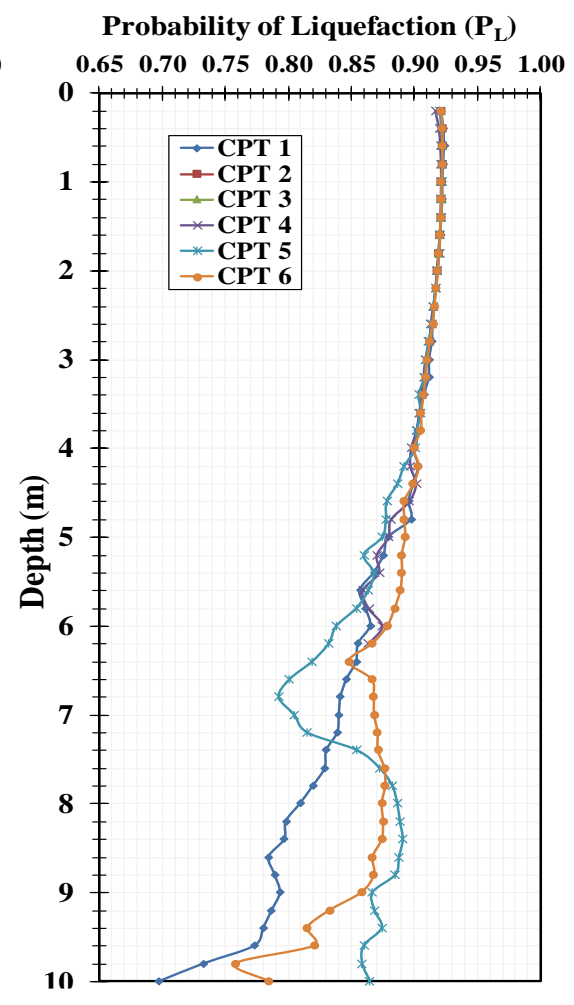

(b)

Figure 3. Analysis of liquefaction (a) Factor of safety against liquefaction, (b) Probability of liquefaction 


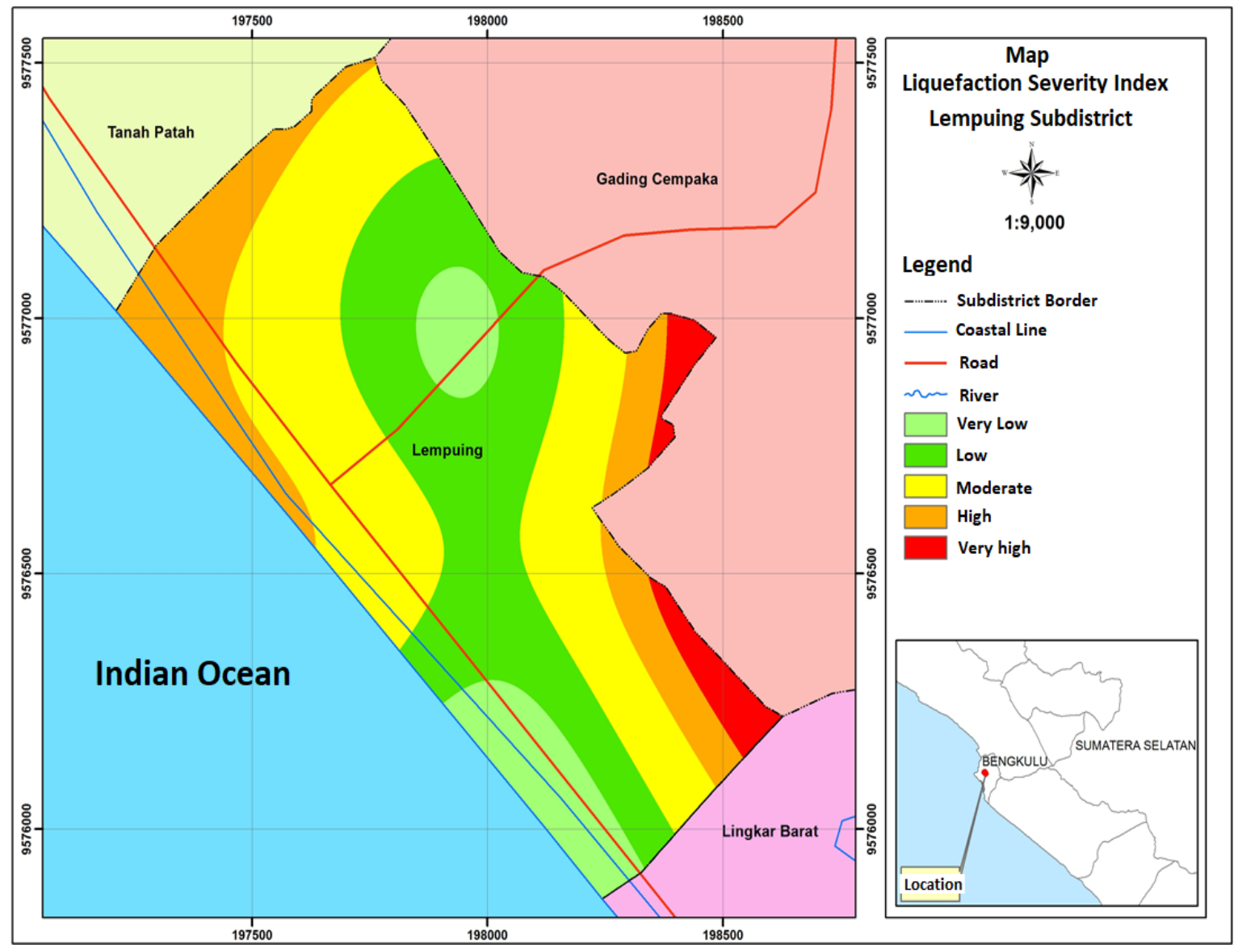

Figure 4. Liquefaction susceptible area based on LSI in Lempuing Subdistrict

\section{LSI in Lempuing subdistrict}

Iwasaki et al. (1982) also mentioned that the necessary to interpret the micro-zonation of liquefaction potential is important in liquefaction countermeasure and mitigation effort. Therefore, the liquefaction hazard zonation is important. Sonmez and Gokceoglu (2005) suggested that the results of liquefaction probability analysis are capable of describing the distribution of the level of susceptible area based on the severity index method. In this study, by following the LSI method, the factor of safety and probability of liquefaction that obtained from the previous analysis are combined to analyze the Liquefaction severity index ( $L S I)$. The result of $L S I$ is interpreted in Table 2 as follows,

Table 2. Analysis of LSI

\begin{tabular}{|c|c|c|}
\hline \multirow{2}{*}{ CPT } & Liquefaction severity index & \multirow{2}{*}{ Criteria } \\
\hline & (LSI) & \\
\hline 1 & 68.321 & High \\
\hline 2 & 17.792 & Low \\
\hline 3 & 22.713 & Low \\
\hline 4 & 48.462 & Moderate \\
\hline 5 & 68.567 & High \\
\hline 6 & 68.863 & Very high \\
\hline
\end{tabular}

\section{Map of LSI}

Based on the result summarized in Table 2, CPT 1 is categorized as a high-risk area to undergo liquefaction. The analysis of liquefaction potential in CPT 5 and CPT 6 also results in the same criteria as CPT 1. Moderate risk area is detected in CPT 4, whereas low-risk area is detected in CPT 3 and CPT 2. The result summarized in Table 2 is depicted in the susceptibility map, which is shown in Figure 4. Based on the analysis result, Lempuing Subdistrict was categorized as very high to very low susceptible to liquefaction. In general, the vulnerability level of liquefaction in study area is strongly influenced by the existence of stiff layers at shallow depth. Based on the site investigation, the stiff layers are found at shallow depth, especially for CPT-1 and CPT-2. It indicates that there are only thin sand layers which can undergo liquefaction in those sites. Since LPI is calculated considering the depth, LPI is therefore relatively small in CPT-1 and CP-2.

It can be generally concluded that the estimation of peak ground acceleration provide by SNI 03-17262012 could trigger liquefaction in Lempuing Subdistrict. Mase (2017b) and Mase and Somantri 
(2016a and 2016b) also mentioned that subsoils of Lempuing Subdistrict could be very vulnerable to undergo liquefaction during the 2007 BengkuluMentawai earthquake.

The very high susceptible area was located on the eastern Lempuing Subdistrict (red shading) bordering Gading Cempaka Subdistrict. The high susceptible area is located on the Northern Lempuing Subdistrict bordering the Tanah Patah Subdistrict (orange shading). Moderate (yellow shading), low (dark-green shading), and very low (light green shading) susceptible area are located in the middle, west, and south of Lempuing Subdistrict.

Generally, the results of this study are relatively consistent with the study of Mase (2019), who investigated the geophysical characteristic of subsoils in Ratu Agung District, including Lempuing Subdistrict. Mase (2019) implemented the horizontal to vertical spectral ratio (HVSR) technique suggested by Nakamura (1989), to investigate the goophysical characteristic of Ratu Agung District. Based on geophysical investigation performed Mase (2019), areas in Lempuing Subdistrict are dominated by sandy soils. Mase (2019) also confirmed the report of Hausler and Anderson (2007) who mentioned that liquefaction was found on Lempuing Subdistrict.

According to several studies, the liquefaction might be analyzed up to $20 \mathrm{~m}$ deep. In CPT 1 to CPT 6 , the maximum depth obtained is only at $10 \mathrm{~m}$ deep, and it is not fulfilling the suggested analysis depth. Because LSI analysis is based on the function of integration, then analysis using deeper soil data would produce a better interpretation of liquefaction risk and more accurate. However, this study has given an overview of liquefaction in the Lempuing Subdistrict. The result of this study is not only influenced by analyzed depth but also influenced by the distribution of CPT points. The accuracy of the map depends on the number of data available. This is very important to analyze the susceptible area of liquefaction

\section{Concluding Remarks}

This paper presents a liquefaction vulnerability of Lempuing Subdistrict, Bengkulu City, Indonesia. The site investigations were performed and the liquefaction potential analysis was performed. The zonation of liquefaction vulnerability was also composed to observe the level of vulnerability in the study area.

Generally, Soil condition in Lempuing Subdistrict is clearly dominated by sandy soil. It is very potential to undergo liquefaction. The factor of safety against liquefaction $\left(F_{S}\right)$ and probability of liquefaction $\left(P_{L}\right)$ in Lempuing Subdistrict showed that Lempuing Subdistrict is categorized as the vulnerable area to undergo liquefaction. In general, Lempuing Subdistrict was categorized as very high to very low susceptible to liquefaction. The results of this study are also consistent with the previous studies and field evidences found during the 2007 Bengkulu-Mentawai Earthquake. The results of this study would recommend considering the liquefaction impact in the study area.

\section{Acknowledgment}

This study is also supported by the Competitive Research of University Bengkulu, (2019) No: 2170/UN30.15/LT/2019 and the International Collaboration Research of University Bengkulu (2019) No: 2183/UN30.15/LT/2019. Author would like to express thanks to the Soil Mechanics Laboratory of Civil Engineering, Faculty of Engineering, the University of Bengkulu, Indonesia, for assisting CPT test in Lempuing Subdistrict.

Author would like to gratitude big thanks to all people who involved and contributed in this study. Author also would like to thank Ms. Anggi Nidya Sari, M.Eng., from Department of Civil Engineering, Sriwijaya State Polytechnic, Palembang, Province of South Sumatra, Indonesia for assistance in depicting the liquefaction vulnerability zonation.

\section{References}

Hakam, A. (2012). Soil Liquefaction in Padang due to Padang Earthquake 30 September 2009. Civil Engineering Dimension 14(2), 64-68.

Hausler, E. \& Anderson, A. (2007). Observation of the12 and 13 September 2007 Earthquake, Sumatra, Indonesia. Build Change Report, Denver, Colorado, USA.

Iai, S., Matsunaga, Y., \& Kameoka, T. (1992). Strain Space Plasticity Model for Cyclic Mobility. Soils and Foundations 32(2), 1-15.

Idriss, I. M. (1999). An Update to the Seed-Idriss Simplified Procedure for Evaluating Liquefaction Potential. Presented at TRB Workshop on New Approaches to Liquefaction, (FHWA-RD-99-165), USA, Federal Highway Administration.

Idriss, I. M., \& Boulanger, R. W. (2008). Soil liquefaction during earthquakes, Earthquake Engineering Study Institute (EERI), USA. 
Iwasaki, T., Tokida, K., Tatsuoka, F., Watanabe, S., Yasuda, S., \& Sato, H. (1982). Microzonation for Soil Liquefaction Potential using Simplified Methods, presented at 2nd International Conference on Microzonation, 1319-1330, Seattle, USA.

Juang, C. H., Yuan, H., Lee, D. H., \& Lin, P. S. (2003). Simplified CPT-based Method for Evaluating Liquefaction Potential of Soils. Journal of Geotechnical and Geoenvironmental Engineering ASCE 129 (I), 66-80.

Mase, L. Z. (2017b). Liquefaction Potential Analysis Along Coastal Area of Bengkulu Province Due to the $2007 \mathrm{Mw}$ 8.6 Bengkulu Earthquake. Journal of Engineering and Technological Sciences, 49(6), 721-736.

Mase L. Z., \& Somantri A. K. (2016b). Analisis Potensi Likuifaksi di Kelurahan Lempuing Kota Bengkulu menggunakan Percepatan Maksimum Kritis. Jurnal Potensi, 18(1), 51-61.

Mase, L. Z. (2017a). Shaking Table Test of Soil Liquefaction in Southern Yogyakarta. International Journal of Technology, 8 (4), 747-760.

Mase, L. Z. (2019). Seismic Vulnerability Maps of Ratu Agung District, Bengkulu City, Indonesia. Civil Engineering Dimension, 21(2), 97-106.

Mase, L. Z., \& Somantri, A. K. (2016a). Liquefaction Study using Shear Wave Velocity (Vs) Data Incoastal Area of Bengkulu City. Presented at Seminar of Indonesian Geotechnical Engineering Society, Yogyakarta (81-86), Yogyakarta, Indonesia, Indonesian Geotechnical Engineering Society.

Mase, L. Z. (2018). Studi Kehandalan Metode Analisis Likuifaksi menggunakan SPT Akibat Gempa 8,6 Mw, 12 September 2007 di Area Pesisir Kota Bengkulu. Civil Engineering Journal, 25(1), 53-60.

Mase, L. Z \& Sari, A. N. (2015). A Preliminary Evaluation of Liquefaction Potential in Lempuing Subdistrict, Bengkulu City. Jurnal Inersia, 2(15), 21-25.

Mase, L. Z. (2015). Karakterisktik Gempa di Bengkulu. Jurnal Teknosia, 2(15), 25-34. Technical Research Institute: Quarterly Reports, 30(1), 25-33.
Misliniyati, R., Mawardi, Besperi, Razali, M.R., \& Muktadir, R. (2013). Pemetaan Potensi Likuifaksi Wilayah Pesisir berdasarkan Data Cone Penetration Test di Kelurahan Lempuing, Kota Bengkulu. Journal of Inersia, 5(2), 69-75.

Monalisa A. (2014). Analysis of Liquefaction Potential Using Simple Probability Method Based on CPT Data in Lempuing Subdistrict", Bengkulu City, Bachelor Thesis, Indonesia: Department of Civil Engineering, Faculty of Engineering, University of Bengkulu.

Nakamura, Y. (1989). A Method for Dynamic Characteristics Estimation of Subsurface using Microtremor on the Ground Surface, Railway

Robertson, P. K., \& Wride, C. E. (1998). Evaluating Cyclic Liquefaction Potential using The Cone Penetration Test. Canadian Geotechnical Journal, 35(3): 442-59.

Seed, H. B. (1983). Earthquake Resistant Design of Earth Dams, presented at Symposium on Seismic Design of Embankments and Caverns ASCE (4164), ASCE, Pennsylvania, New York.

Seed, H. B., \& Idriss, I. M. (1971). Simplified Procedure for Evaluation Soil Liquefaction Potential. Journal of Soil Mechanics and Foundation ASCE, 97(9), 1249-1273.

SNI 03-1726-2012, 2012. Standard of earthquake resistance design for building, national standardization agency, Jakarta, Indonesia [in Bahasa Indonesia]

Sonmez, H \& Gokceoglu, C. (2005). A Liquefaction Severity Index Suggested for Engineering Practice, Environmental Geology, 48(1), 81-89.

Yogatama, B. A. \& Fathani, T. F. (2013). Liquefaction Potential Analysis on Bantul Regency and Yogyakarta City Area, presented at 17th Annual Scientific Meeting of the Indonesian Geotechnical Engineering Society (206-211), Jakarta, Indonesia, Indonesian Geotechnical Engineering Society.

Youd, T. L., \& Idriss, I. M. (2001). Liquefaction Resistance of Soils: Summary Report from the 1996 NCEER and 1998 NCEER/NSF Workshops on Evaluation of Liquefaction Resistance of Soils. Journal of Geotechnical and Geoenvironmental Engineering ASCE, 127(4), 297-313. 